\title{
A TEN-YEAR FOLLOW-UP OF HUMAN LEPTOSPIROSIS IN URUGUAY: AN UNRESOLVED HEALTH PROBLEM
}

Felipe SCHELOTTO(1), Elba HERNÁNDEZ(1), Sabina GONZÁLEZ(1), Alicia DEL MONTE(1), Silvana IFRAN(1), Karina FLORES(1), Lorena PARDO(1), Daniel PARADA(2), Mercedes FILIPPINI(2), Victoria BALSEIRO(1), Juan Pablo GEYMONAT(1) \& Gustavo VARELA(1)

\begin{abstract}
SUMMARY
Leptospira spp. are delicate bacteria that cannot be studied by usual microbiological methods. They cause leptospirosis, a zoonotic disease transmitted to humans through infected urine of wild or domestic animals. We studied the incidence of this disease in the Uruguayan population, its epidemiologic and clinical features, and compared diagnostic techniques. After examining 6,778 suspect cases, we estimated that about 15 infections/100,000 inhabitants occurred yearly, affecting mainly young male rural workers. Awareness about leptospirosis has grown among health professionals, and its lethality has consequently decreased. Bovine infections were probably the principal source of human disease. Rainfall volumes and floods were major factors of varying incidence. Most patients had fever, asthenia, myalgias or cephalalgia, with at least one additional abnormal clinical feature. 30-40\% of confirmed cases presented abdominal signs and symptoms, conjunctival suffusion and altered renal or urinary function. Jaundice was more frequent in patients aged $>40$ years. Clinical infections followed an acute pattern and their usual outcome was complete recovery. Laboratory diagnosis was based on indirect micro-agglutination standard technique (MAT). Second serum samples were difficult to obtain, often impairing completion of diagnosis. Immunofluorescence was useful as a screening test and for early detection of probable infections.
\end{abstract}

KEYWORDS: Human leptospirosis; Bovine source; Rainfall; MAT.

\section{INTRODUCTION}

Leptospirosis is a widely spread zoonotic disease caused by pathogenic Leptospira spp. These are long, spiral, Gram negative bacteria ${ }^{11,24}$ that cannot be easily studied by conventional microbiological procedures: slender organisms, $0.1 \mu \mathrm{m}$ in diameter, not usually seen in stained smears, but observed alive with active motility through dark-field microscopy. Cultures require bovine albumin or rabbit serum, vitamins and unsaturated fatty acids; growth is clearly seen after 5-7 days in liquid media. These characteristics have led clinical microbiologists to prefer techniques based on the detection of the immune response, not readily available in routine medical microbiology laboratories. Micro-Agglutination Technique (MAT) is considered as the reference standard $^{12}$. More recently, molecular biological tools still requiring proper standardization have been proposed for the diagnosis ${ }^{45,48}$. Reagents used for indirect tests require including main antigens found in local or regional prevalent strains; these comprise antigenic variants that frequently produce useful cross-reactions. The serovar is accepted as the basis of Leptospira taxonomy at the sub-specific level ${ }^{12}$. LPS antigenic determinants allowed defining 220 serovars of pathogenic L. interrogans and 60 of saprophytic L. biflexa. DNA studies of both circular leptospiral chromosomes ${ }^{42}$ have now identified 17 genospecies, having little correlation with the traditional phenotypic classification ${ }^{34,43}$.

Kidneys of infected rodents and of many wild, domestic or production mammals are the reservoir of Leptospira spp. ${ }^{40}$. Human infection results from exposure to urine from these animals, directly or through contamination of water, surfaces or tools. The port of entry is mainly the skin, mildly or overtly abraded, the mucous membranes or the conjunctiva ${ }^{23}$.

Leptospirosis is a common infection of domestic and production animals in Uruguay ${ }^{37}$ but has only recently been fully recognized by many health care professionals as an important human health problem.

Before 2000, few human cases of leptospirosis were reported annually to the Health Department, and infections were recognized when illness progressed to severe disease or death ${ }^{26,49}$. The close contact of humans and animals in Uruguayan farms or urban environments, and the high frequency of detected bovine, ovine, swine and canine infections with Leptospira spp. led us to suspect a higher than reported figure of human disease.

Here we report the results of a study developed to estimate the

(1) Bacteriology and Virology Department, Institute of Hygiene, Universidad de la República, Montevideo, Uruguay.

(2) Florida Medical Cooperative, Uruguay.

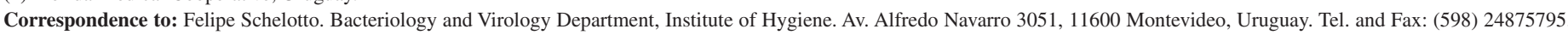
E-mails: felipe@ higiene.edu.uy / gvarela@ higiene.edu.uy 
SCHELOTTO, F.; HERNÁNDEZ, E.; GONZÁLEZ, S.; DEL MONTE, A.; IFRAN, S.; FLORES, K.; PARDO, L.; PARADA, D.; FILIPPINI, M.; BALSEIRO, V.; GEYMONAT, J.P. \& VARELA, G. - A ten-year follow-up of human leptospirosis in Uruguay: an unresolved health problem. Rev. Inst. Med. Trop. Sao Paulo, 54(2): 69-75, 2012.

incidence of human infections, define their local epidemiologic features and determine the actual signs and symptoms of leptospirosis in our population. We also evaluated indirect immunefluorescence as a screening diagnostic test.

\section{MATERIALS AND METHODS}

Patients and sera: Paired sera 10-15 days apart were requested from cases recruited on the basis of these criteria: a) a compatible epidemiological background: dairy farm, rice field, forest or rural jobs in general; marshland, wetland, sewage, wastewater, garbage or rubble workers; people involved in fruit and vegetable markets; flood victims; recent recreational swimming in stagnant water; abundant rodent population; close contact with ruminants, pigs, animal feeds; b) presence of suggestive clinical features: sudden onset of fever, or persistent fever without etiological diagnosis, along with one or more of these additional signs or symptoms: myalgias, asthenia, headache, photophobia, "aseptic" meningitis; conjunctival suffusion; urinary pathology, haematuria, oliguria; abdominal pain, vomiting, nausea, jaundice, hepatomegaly; chest pain, cough, haemoptysis, respiratory distress; c) presence of laboratory or imaging signs: leucocytosis with neutrophilia; high erythrocyte sedimentation rate; elevated azotemia or serum creatinine, proteinuria or other urinalysis abnormalities; bilirubin (specially indirect type), aminotransferase elevation or other signs of enzyme alteration and liver dysfunction; chest x-ray infiltrates. A small subset of patients was included after serum immunochromatographic strip tests performed by first-level laboratories yielded presumptively positive results.

Standard data on epidemiological, clinical and complementary features were recorded from suspect cases and gathered for statistical analysis.

\section{Microbiological procedures}

Culture media and strains: Fletcher semisolid medium ${ }^{12}$ with inactivated rabbit serum ${ }^{4,9,10}$ was used for stock strain cultures. When requested, this medium with added $2 \%$ EMJH enrichment was used for blood or urine cultures. Defined EMJH medium or Stuart broth with rabbit serum were employed for obtaining liquid cultures for use as antigens in indirect diagnostic procedures (all media were from Difco-BD ${ }^{\circledR}$, Becton, Dickinson and Co. Sparks, MD 21152, USA).

Reference strains were kindly provided by local and regional laboratories: INEI "Carlos G. Malbrán”, Argentina (National Institute of Infectious Diseases); INTA Castelar, Argentina (National Institute of Agricultural Technology); Universidade Federal de Pelotas, Brazil; DILAVE "Miguel C. Rubino", Uruguay (Veterinary Laboratories Division).

Stock cultures of serovars Australis, Autumnalis, Ballum, Bataviae, Bratislava, Butembo, Canicola, Celledoni, Cynopteri, Grippotyphosa, Hardjo, Hebdomadis, Icterohaemorrhagiae, Mini, Patoc, Pomona, Pyrogenes, Sejroe, Tarassovi and Wolffi were kept in semisolid media at room temperature in the dark and renewed after 45-60 days. Fresh liquid cultures of these strains were inoculated weekly and incubated at $28^{\circ} \mathrm{C}$ for seven days. Strains showing autoagglutination or potentially contaminated cultures were membrane filtered, intraperitoneally inoculated in meriones or guinea pigs ${ }^{12}$, and recovered as fresh cultures from cardiac blood.

MAT (Micro Agglutination Technique): MAT was performed in all cases according to the standard technique ${ }^{12}$ with a two-step procedure. Each serum was initially diluted $1: 25$ in saline and $100 \mu \mathrm{L}$ were mixed in plastic plate wells with $100 \mu \mathrm{L}$ of each of 20 live cultures of Leptospira serovars frequently detected in the region, or capable of crossreactions. Liquid cultures were 7-15 days old, and turbidity matched to McFarland 0.5. After one min of rotary mixing, the plates were incubated under standard conditions ${ }^{38}$. A positive reaction was observed when microclumps could be detected in a dark-field microscope and less than $50 \%$ of the live Leptospira remained free from agglutination. Positive and negative control sera were included in each plate.

In a second step, serovars that produced a positive result and did not show auto-agglutination or false positive results in negative control were tested against serial dilutions of the patient's serum.

Normal antibody levels and cut-off titers were defined through preliminary evaluation of 145 samples from human blood bank donors, and 31 of people considered at risk from two sources: apparently normal workers of a small city's wastewater plant and students attending a dairy technical school. Observed titers in these samples were never higher than 50 or 100 for one or a few serovars (Fig. 1). A threshold of 200 was considered acceptable.

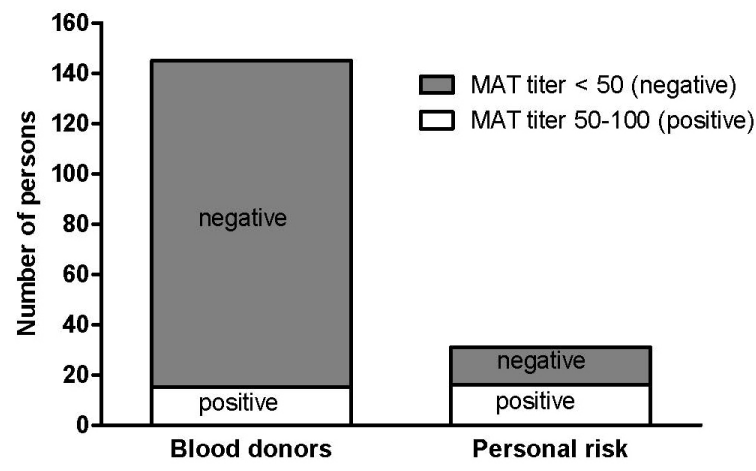

Fig. 1 - MAT titer treshold based on non-ill persons.

Comparing these figures with high titers found in sick patients, a positive reaction of up to $1 / 400$ dilution of the first serum against at least one serovar (usually accompanied by similar or weaker reactions with other strains) was considered diagnostic, in accordance with criteria reported by FAINE et al. ${ }^{12}$. Otherwise, a high titer $(>400)$ in the second serum, or a fourfold increase in titers from acute to convalescent sample were also interpreted as confirmed results.

A test showing a 200 titer for one serovar or several 100 reactions for various serovars was informed as suggestive of infection. If the second serum, or even a requested third, yielded similar results, they were interpreted as expressing past infection or cross-reacting antibodies due to another disease.

A second sample could not always be obtained for completing MAT diagnosis. 


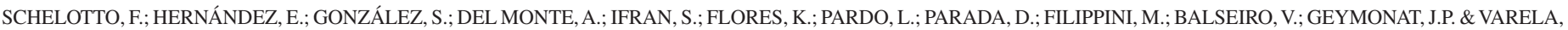
G. - A ten-year follow-up of human leptospirosis in Uruguay: an unresolved health problem. Rev. Inst. Med. Trop. Sao Paulo, 54(2): 69-75, 2012

Immunofluorescence (IF) indirect test: Based on reports of an early rise in IF-reacting antileptospiral antibodies ${ }^{2,44}$, IF was tried to quickly screen for infected persons, as described by TORTEN et al. ${ }^{47}$ with minor adjustments. Pyrogenes, Bratislava, Icterohaemorragiae and Pomona serovars, frequently reacting strains in MAT, were used for preparing the IF antigen mix. Equal parts of liquid cultures (7-8 days old: $10^{7}$ bacteria/ $\mathrm{mL}$ approx.) were combined and two loopfuls of mixture were transferred to spots on IF slides, allowed to dry for $10 \mathrm{~min}$ at $40{ }^{\circ} \mathrm{C}$ and fixed with acetone; human sera ( $35 \mu \mathrm{L}, 1: 100$ dilutions in sterile PBS) were added and incubated in a moist chamber for $30 \mathrm{~min}$. at $37^{\circ} \mathrm{C}$; after being washed twice for five minutes with $0.15 \mathrm{M}$ PBS $\mathrm{pH} 7.2$, the slides were air dried, $35 \mu \mathrm{L}$ of anti human $\operatorname{IgM}$, IgG and IgA mouse antibodies labeled with fluorescein isothiocyanate (FITC conjugate, Sigma Aldrich ${ }^{\circledR}$, St Louis MO 63103, USA) were added and incubated $30 \mathrm{~min}$ at $37^{\circ} \mathrm{C}$; following washing and air-drying, the coverslips were placed over buffered glycerol, and slides were examined in an epifluorescence microscope (Nikon) with 400x amplification. Readings were compared with negative and positive controls, including sera with high titers and with antibody levels close to threshold.

IF was practiced in 570 early samples of cases that were subsequently studied through MAT by a different laboratory worker. The results of comparative analysis are shown in Table 1.

Table 1

Evaluation of Indirect Immunofluorescence (IF) as compared with microagglutination Technique (MAT)

\begin{tabular}{lcccc}
\hline MAT result & positive & negative & unresolved & total \\
\hline No. cases & 173 & 112 & 285 & 570 \\
Positive IF & 117 & 10 & 70 & 197 \\
Negative IF & 56 & 102 & 215 & 373 \\
\hline
\end{tabular}

Data analysis: Specificity and sensitivity of IF were determined in comparison with MAT. Chi square test was used for excluding the independence between two variables when examining clinical and outcome results. Statistical analyses were performed using Epi Info 6 software for Windows.

Ethical Guidelines: Informed consent was obtained from all human participants, and approval was delivered by Medicine Faculty Ethics Commission. Animals were treated as specified by University Honorary Commission for Animal Experimentation.

\section{RESULTS}

From December 2000 to December 2010, we studied sera from 6,778 patients. In total, more than 10,000 samples were examined with MAT.

Blood cultures were performed for 136 cases and urine cultures in 28 occasions. Three strains were recovered from blood, but only one was available for further studies. The strain was identified as $L$. interrogans serovar Pomona in the WHO/OIE/FAO Collaborating Centre for Reference and Research on Leptospirosis, Communicable Diseases Unit, Queensland, Australia.

MAT and IF as diagnostic tools: The inability to obtain second samples led to numerous undefined MAT results: 520 of the first 1000 studied cases, yielding only 193 negative and 287 positive confirmed cases. In MAT positive samples, reactions were usually multiple, involving several strains with different serum titers. Bratislava, Pyrogenes, Mini, Patoc and Icterohaemorrhagiae serovars were the most frequently reacting, showing positive results in more than $50 \%$ of patients (Fig. 2).

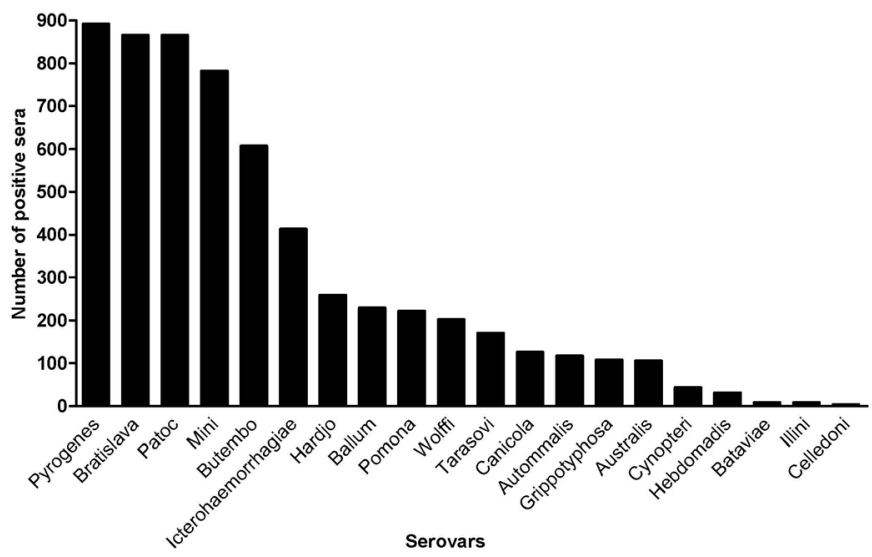

Fig. 2 - MAT - reactive serovars.

Sensitivity of IF in initial samples was found to be $67.63 \%$ as compared with MAT, and specificity was $91.07 \%$. Positive predictive value was $92.13 \%$ (Table 1 ).

40 of 78 patients with initial negative and second positive MAT results were positive in first sample testing with IF, revealing the value of IF in early detection.

70 of 285 patients without confirmed result (no second sample) yielded a positive IF reaction; 64 of them $(22.35 \%)$ could have been confirmed with a complete MAT.

Number and distribution of MAT confirmed cases: 945 leptospiral infections were confirmed by MAT during the study period.

Numbers varied from year to year, peaking in 2002-3, 2007 and 2010, when floods affected extended populations throughout the country (Table 2). Each year, most infections occurred during rainy months (end of summer, autumn and spring in this region, Fig. 3).

The vast majority of individuals with positive diagnosis of Leptospira infection were found to live outside the department of Montevideo (almost 85\%: 802 confirmed sick persons), although nearly half the population of the country actually resides within this department, including the capital of the country. Departments where dairy production is concentrated (Florida, Colonia) showed the highest rates of infection.

The proportion of urban cases was relatively higher during years of low general incidence (19.5\% for Montevideo in 2004-2005).

Male patients accounted for more than $93.5 \%$ of total confirmed cases; they were mainly (50\%) young rural workers aging 20 to 40 years (Fig. 4). Infected children were seldom diagnosed. 


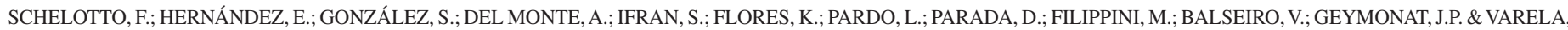
G. - A ten-year follow-up of human leptospirosis in Uruguay: an unresolved health problem. Rev. Inst. Med. Trop. Sao Paulo, 54(2): 69-75, 2012.

Table 2

Annual MAT confirmed cases of leptospirosis and reported deaths in Uruguay

\begin{tabular}{lcc}
\hline Year & No. of cases & No. of deaths \\
\hline 2000 & 23 & 5 \\
2001 & 58 & 7 \\
2002 & 155 & 2 \\
2003 & 118 & 6 \\
2004 & 45 & 2 \\
2005 & 89 & 3 \\
2006 & 60 & 0 \\
2007 & 138 & 2 \\
2008 & 62 & 0 \\
2009 & 43 & 0 \\
2010 & 154 & 1 \\
\hline Total & $\mathbf{9 4 5}$ & $\mathbf{2 8}$ \\
\hline
\end{tabular}

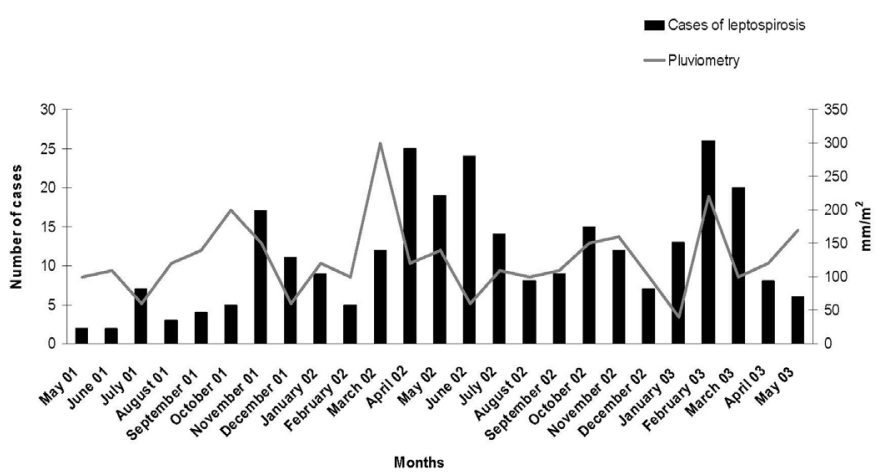

Fig. 3 - Monthly number of cases in relation to rainfall. May 2001 - May 2003.

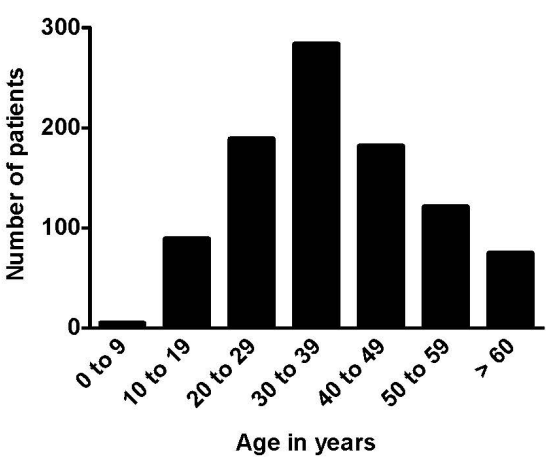

Fig. 4 - Age of the patients with leptospirosis.

Rural activities performed by most infected people (57\%) were mainly in dairy farming, bovine and ovine animal raising, agriculture, rice growth and harvest, foresting and lumbering. 14\% of the patients were involved in other risk jobs. Unemployed workers, students, office employees, and people developing other activities not listed represented a minor proportion of the infected cases. Records were available for 498 positive patients.
Clinical features of patients: Thorough clinical records were obtained from 491 confirmed cases (Table 3). Fever, asthenia, myalgias and cephalalgia were present in 80 to $100 \%$ of these patients. Most patients showed at least one additional abnormal clinical feature. Vomits and other abdominal or hepatic signs and symptoms; conjunctival suffusion and signs of altered renal or urinary function (haematuria, proteinuria, piuria) were present in 30 to $40 \%$ of confirmed cases. Cough or other respiratory features, (sometimes haemoptysis or acute distress) occurred in 20 to $30 \%$ of cases. Photophobia accompanied headache almost $30 \%$ of times. Neurological abnormalities (meningitis, transient confusion) or petechiae seldom appeared.

Table 3

Symptoms and signs of 491 fully recorded cases

\begin{tabular}{lcc}
\hline Symptoms and signs* & No. & $(\mathbf{\%})$ \\
\hline Fever & 462 & $(94.1)$ \\
Asthenia & 422 & $(86)$ \\
Myalgia & 420 & $(85.6)$ \\
Headache & 398 & $(81)$ \\
Photophobia & 52 & $(10.5)$ \\
Neurological & 21 & $(4.2)$ \\
Vomiting & 196 & $(40)$ \\
Abdominal pain & 147 & $(30)$ \\
Icterus & 133 & $(27)$ \\
Hepatomegaly & 52 & $(10.5)$ \\
Cough & 108 & $(22)$ \\
Expectoration & 77 & $(15.6)$ \\
Chest pain & 44 & $(8.9)$ \\
Acute Renal Failure and Urinary Disorders & 167 & $(34)$ \\
Conjunctival hiperemia & 162 & $(33)$ \\
Petechiae & 21 & $(4.2)$ \\
\hline Total & $\mathbf{4 9 1}$ & $(\mathbf{1 0 0})$ \\
\hline
\end{tabular}

*List was ordered in groups according to organic systems or regions

Icteric forms were more frequent in patients aged $>40$ years. Records showed 62 icteric cases in a total of 304 patients aged $<40$ years, and 71 in 187 older persons. (Chi-square independence test $\chi^{2}=18.104, p$-value $=0.00002092$ ). Hepatomegaly presented a similar age distribution, but figures were globally lower.

The occurrence of neurological, respiratory and even abdominal symptoms and signs sometimes misled or delayed diagnosis from unaware health personnel.

Most clinically overt infections presented an acute pattern and their usual outcome were complete recovery. Records on clinical evolution were incomplete regarding number of patients requiring hospitalization or admission to Intensive Care Units.

The number of annual deaths due to leptospirosis was never above 10, 


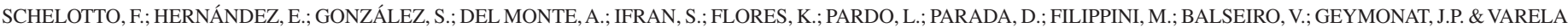
G. - A ten-year follow-up of human leptospirosis in Uruguay: an unresolved health problem. Rev. Inst. Med. Trop. Sao Paulo, 54(2): 69-75, 2012

peaking at seven reported cases in 2001, six in 2003 and descending to 0 in recent years of low incidence (Source: Health Ministry Surveillance Service, Table 2). Comparative figures were 25 deaths for 488 patients during the 2000-2005 period, and three out of 457 from 2006 to 2010 (Chi-square independence test, Yates correction $\chi^{2}=14.858, p$-value $=$ 0.00011592).

\section{DISCUSSION}

Human leptospirosis is probably not a truly emerging disease in Uruguay, but merely a neglected infection favored by close animal to human contact derived from social and economic conditions.

Before 2000, leptospiral infections were mainly a concern to veterinarians and people involved in meat and dairy production, due to frequent bovine abortion and economic loss. Diagnostic facilities were designed to detect animal infections, but were not available in human health care centers. Low levels of clinical awareness and difficulties in laboratory diagnosis have thus contributed to delay facing this serious threat to human health. During the previous century, reported human cases were scarce, and apparent lethality was high, because only severe cases were attended and reported. In 1998, 13 human cases and three deaths were recorded by the Health Department; in 1999, eight patients with leptospirosis and no death.

Proper surveillance and record of cases ${ }^{51}$ has progressively contributed to knowledge, concern of health workers, and detection of less severe infections.

A larger annual incidence has been identified since 2000-2001, and lethality has significantly decreased in the last years. Early diagnosis favoring adequate management of the disease, general improvement of social conditions and a new National Health System may have contributed.

The results we present are mainly based on MAT. Focusing on the 2001/2010 period of surveillance, they reveal an average public health burden of 90-100 confirmed infections per year. If we had validated IF results or regularly obtained a second sample for MAT studies, this figure could have climbed to an estimate of 120/year. Considering that the total population of the country is approximately $3,350,000^{31}$, that not all patients are studied or reported, and that many mild cases usually occur for each overtly clinically ill person ${ }^{12}$, we can estimate that at least 500 human infections may develop annually in Uruguay, revealing a human leptospirosis incidence of about 15/100,000 inhabitants/year. When compared to similar estimates in other countries, this is a very high figure for Uruguay ${ }^{4,20,50}$.

Annual incidence rate variation is closely related to weather and rainfall, which explains 2002-3, 2007 and 2010 peaks, but other factors are also important. In 2004 and part of 2005 rainfall figures were still heavy, but incidence fell abruptly. Regional economic crisis led cattle owners to slaughter older animals, and the large bovine reservoir of infection was then deeply reduced.

Twelve million bovine and 9.5 million ovine ruminants lived on Uruguayan fields in $2008^{31}$ in association with a large population of dogs (approximately 1.2 million) and rodents. Figures vary yearly in relation to economic situation and business. Climate is temperate. Main agriculture products of the country are soy, wheat, rice, barley, and wood for cellulose production.

Territorial distribution of human infections and actual observation of living and working conditions of rural affected population (e.g: lack of adequate protection of young males milking cows against exposure to animal urine, type of disposal of wash water that favors recycling of bacteria) lead to point bovine animals as the main direct source of human leptospirosis, specially in dairy farms. Localized outbreaks involving people, dogs and other animals were seen to coincide with bovine recognized infections and "abortion storms" due to Leptospira spp. ${ }^{14,15,18,21,22,32,37,39}$. Extensive cattle or sheep raising activities were apparently less frequently associated with human infection.

Ruminants and infected pigs, that produce long periods of leptospiruria ${ }^{7,8,16}$ are probably also linked with cases identified in other agriculture or farming organizations. According to our records, a smaller number of human cases, affecting sewage, wastewater, garbage or rubble workers, people involved in fruit and vegetable markets, animal feed production, flood victims or other patients seem to be more directly associated with dogs or rodents, mainly in urban settings or among workers in lumber-wood production ${ }^{17,29,30,40}$.

The epidemiological pattern of most cases of Uruguayan leptospirosis probably explains the sex and age distribution of the sick population: milkers and rural workers in general tend to be young or middle-aged males exposed to animal contact or indirect surface contamination with animal urine. Children are rarely equally exposed, except to dogs and rodents in country or urban settings ${ }^{46}$.

Even though local publications have reported cases showing these features ${ }^{6,25,35}$, respiratory, neurological or even abdominal and other signs and symptoms have frequently been the cause of diagnostic hesitation. Health personnel and especially doctors must progress in recognizing protean manifestations of leptospirosis, and in relating clinical presentations with the most probable evolution of the patients $3,5,27,33,36$. More generally, awareness and thorough knowledge about prevalence, characteristics, diagnosis and potential severity of this disease must still improve.

Pediatric infections are rarely identified, and it is still not known whether this is due to actual low incidence linked to epidemiological factors, or to peculiar clinical presentations in this age group.

Although dogs and rodents are usually blamed for leptospiral infections by nurses, human or veterinary doctors and the general population, other domestic or production animals have not yet been fully identified as a source of risk where preventive measures should be focused. Our team is thus developing an educational campaign, reaching small towns, rural enterprises, dairy farms, schools, professional and health centers, community organizations and also regular higher education institutions, to contribute to knowledge and awareness of leptospirosis, its prevention, diagnosis and management.

Laboratory diagnosis has been extensively practiced employing MAT technique; immunofluorescence was shown to reveal probable infections early, but sensitivity was low and readings are known to 
SCHELOTTO, F.; HERNÁNDEZ, E.; GONZÁLEZ, S.; DEL MONTE, A.; IFRAN, S.; FLORES, K.; PARDO, L.; PARADA, D.; FILIPPINI, M.; BALSEIRO, V.; GEYMONAT, J.P. \& VARELA, G. - A ten-year follow-up of human leptospirosis in Uruguay: an unresolved health problem. Rev. Inst. Med. Trop. Sao Paulo, 54(2): 69-75, 2012.

be strongly dependent on personal skill and criteria. Other indirect methods with similar or better performance than IF are being tried in our laboratory: ELISA and macroagglutination ${ }^{1,28}$. MAT usually identifies cross-reactivity of several serovars against positive sera, so infecting strains cannot be characterized with this method, and should be detected through direct techniques. At present, we are not thus able to determine if different clinical or epidemiological presentations of the disease are linked to different infecting strains.

In a reduced number of patients, hemoculture has allowed bacterial isolation, according to usual performance of this procedure in the region.

The incorporation of molecular techniques (real time Polymerase Chain Reaction for obtaining and quantifying bacterial DNA, Restriction Fragment Length Polymorphism, RAPD and Pulse Field Gel Electrophoresis) will guide in the future the fast and robust detection and identification of infecting Leptospira $\mathrm{spp}^{45,48}$.

Identification of the prevalent sub-specific types in given areas is important as molecular epidemiological knowledge about human and animal strains will provide help in guiding prevention and control measures.

Vaccination with inactivated whole cell preparations has been applied to cattle, and proved useful for controlling abortion when vaccine strains match prevalent animal serovars, but is not clearly suitable for human use due to adverse side effects.

New vaccines, prepared with purified, recombinant surface lipoproteins or other macromolecules derived from most prevalent strains are being developed and will be the key for the prevention of the infection in persons at risk $\mathrm{k}^{9,10,13,19,29,41}$.

\section{RESUMEN}

\section{Diez años de seguimiento de la leptospirosis humana en Uruguay: un problema de salud no resuelto}

El género Leptospira comprende bacterias delicadas, que requieren métodos de estudio especiales. Causan una zoonosis transmitida a los seres humanos por la orina de animales domésticos o silvestres. Estudiamos la incidencia de la leptospirosis en la población humana de Uruguay, sus características epidemiológicas y clínicas, y comparamos técnicas diagnósticas. Tras examinar 6778 casos sospechosos, estimamos que anualmente ocurren unas 15 infecciones/100.000 habitantes, principalmente en trabajadores rurales jóvenes de sexo masculino. El nivel de alerta sobre la leptospirosis ha avanzado en el personal sanitario, y su letalidad ha descendido. La enfermedad humana se asocia principalmente con las infecciones bovinas. Lluvias e inundaciones influyen sobre su incidencia. La mayoría de los pacientes experimentaron fiebre, astenia, mialgias o cefaleas, con al menos un síntoma o signo adicional. 30 a $40 \%$ presentaban sintomatología abdominal, hiperemia conjuntival o alteraciones nefro-urológicas. La ictericia era más frecuente en mayores de 40 años. La enfermedad era habitualmente aguda y la recuperación completa. El diagnóstico de laboratorio se basó en la técnica de microaglutinación (MAT), con cepas vivas de distintos serovares. Se requieren segundas muestras de suero, de difícil obtención. El test de inmunofluorescencia se reveló útil para screening y detección precoz de la infección.

\section{ACKNOWLEDGEMENTS}

This work was partially supported by CSIC (Central Research Committee, UdelaR), and by National Research and Innovation Agency (ANII) of Uruguay. We thank the help provided by Drs. Daniel Casales, Daniel Briano, Carlos Thomas, Virginia Diana, Luis Jorge, José Campione and Hugo Calvo.

\section{REFERENCES}

1. Adler B, Murphy AM, Locarnini SA, Faine S. Detection of specific anti-leptospiral immunoglobulins $M$ and $G$ in human serum by solid-phase enzyme-linked immunosorbent assay. J Clin Microbiol. 1980;11:452-7.

2. Appassakij H, Silpapojakul K, Wansit R, Woodtayakorn J. Evaluation of the immunofluorescent antibody test for the diagnosis of human leptospirosis. Am J Trop Med Hyg. 1995;52:340-3.

3. Bal AM. Unusual clinical manifestations of leptospirosis. J Postgrad Med. 2005;51:17983.

4. Barcellos C, Chagastelles Sabroza P. The place behind the case: leptospirosis risks and associated environmental conditions in a flood-related outbreak in Rio de Janeiro. Cad Saúde Pública. 2001;17(Suppl):59-67.

5. Bharti AR, Nally JE, Ricaldi JN, Matthias MA, Díaz MM, Lovett MA, et al. Leptospirosis: a zoonotic disease of global importance. Lancet Infect Dis. 2003;3:757-71.

6. Breijo M, Servioli L, De León A, Mencía X, Piñeyrúa M, Zimalkovski N. Leptospirosis con compromiso respiratorio predominante. Presentación de cinco casos clínicos. Rev Med Urug. 2006;22:220-5.

7. Caffarena RM, Cacchione RA, Cascelli ES, Martínez ES. Avances en leptospirosis en el Uruguay. Rev Urug Pat Clín Microbiol. 1971;9:186-94.

8. Caffarena RM, Agorio M, Barriola J. Comprobaciones serológicas de brucelosis y leptospirosis en suinos de la República Oriental del Uruguay. An Fac Vet. 1966;11(9):93-103.

9. Cullen PA, Xu X, Matsunaga J, Sánchez Y, Ko AI, Haake DA, Adler B. Surfaceome of Leptospira spp. Infect Immun. 2005;73:4853-63.

10. Eshghi A, Cullen PA, Cowen L, Zuerner RL, Cameron CE. Global proteome analysis of Leptospira interrogans. J Proteome Res. 2009;8:4564-78.

11. Euzéby JP. List of prokaryotic names with standing in nomenclature. Classification of domains and phyla - hierarchical classification of prokaryotes. [cited Febuary 2011]. Available from: http://www.bacterio.cict.fr/classifphyla.html

12. Faine S, Adler B, Bolin C, Perolat P. Leptospira and Leptospirosis. $2^{\text {nd }}$ ed. Melbourne: MediSci; 1999. Reprinted with corrections, May 2000. ISBN 095863260 X

13. Feng CY, Li QT, Zhang XY, Dong K, Hu BY, Guo XK. Immune strategies using singlecomponent LipL32 and multi-component recombinant LipL32-41-OmpL1 vaccines against Leptospira. Braz J Med Biol Res. 2009;42:796-803.

14. Figueiredo AO, Pellegrin AO, Gonçalves VSP, Freitas EB, Monteiro LARC, de Oliveira $\mathrm{JM}$, et al. Prevalência e fatores de risco para a leptospirose em bovinos de Mato Grosso do Sul. Pesq Vet Bras. 2009;29:375-81.

15. Gamage CD, Koizumi N, Muto M, Nwafor-Okoli C, Kurukurusuriya S, Rajapakse JR et al. Prevalence and carrier status of leptospirosis in smallholder dairy cattle and peridomestic rodents in Kandy, Sri Lanka. Vector Borne Zoonotic Dis. 2011;11:10417.

16. García Rodríguez E, Suárez-Hernández M, García-Pérez RP, García-Cabrera R, PedrosoFernández S. Factores de riesgo de la leptospirosis humana en el municipio Ciego de Ávila. Rev Cuba Hig Epidemiol. 2001;39:207-13. 
SCHELOTTO, F.; HERNÁNDEZ, E.; GONZÁLEZ, S.; DEL MONTE, A.; IFRAN, S.; FLORES, K.; PARDO, L.; PARADA, D.; FILIPPINI, M.; BALSEIRO, V.; GEYMONAT, J.P. \& VARELA, G. - A ten-year follow-up of human leptospirosis in Uruguay: an unresolved health problem. Rev. Inst. Med. Trop. Sao Paulo, 54(2): 69-75, 2012.

17. Gautam R, Wu CC, Guptill LF, Potter A, Moore GE. Detection of antibodies against Leptospira serovars via microscopic agglutination tests in dogs in the United States, 2000-2007. J Am Vet Med Assoc. 2010;237:293-8.

18. Giatti-Rodrigues C, Eckehardt-Müller E, de Freitas JC. Leptospirose bovina: sorologia na bacia leiteira da região de Londrina, Paraná, Brasil. Ciênc Rural (Santa Maria). 1999;29:309-14.

19. Haake DA, Champion CI, Martinich C, Shang ES, Blanco DR, Miller JN, et al. Molecular cloning and sequence analysis of the gene encoding OmpL1, a transmembrane oute membrane protein of pathogenic Leptospira spp. J Bacteriol. 1993;175:4225-34.

20. Jansen A, Schöneberg I, Frank C, Alpers K, Schneider T, Stark K. Leptospirosis in Germany, 1962-2003. Emerg Infect Dis. 2005;11:1048-54.

21. Juliano RS, Chaves NST, Santos CA, Ramos LS, Santos HQ, Meireles LR, et al Prevalência e aspectos epidemiológicos da leptospirose bovina em rebanhos leiteiros na microrregião de Goiânia-GO. Ciênc Rural (Santa Maria). 2000;30:857-62.

22. León LL, García RC, Díaz CO, Valdez RB, Carmona GCA, Velázquez BLG. Prevalence of leptospirosis in dairy cattle from small rural production units in Toluca Valley, State of Mexico. Ann NY Acad Sci. 2008;1149:292-5.

23. Levett PN. Leptospirosis. Clin Microbiol Rev. 2001;14:296-326.

24. Levett PN. Leptospira. In: Murray PR, Baron EJ, Jorgensen JH, Landry ML, Pfaller MA, editors. Manual of clinical Microbiology. $9^{\text {th }}$ ed. Washington: ASM Press; 2007. p. 963-70

25. Lombardi R, Varela de Sandler A, Witkind J, Petruccelli D, Campalans LA. Insuficiencia renal aguda en la Leptospirosis. Rev Urug Patol Clin Microbiol. 1972;10:28-36.

26. Lombardi R. Acute renal failure in leptospirosis in Uruguay. Renal Fail. 1997;19:315-8

27. Marotto PC, Nascimento CM, Eluf-Neto J, Marotto MS, Andrade L, Sztajnbok J, et al. Acute lung injury in leptospirosis: clinical and laboratory features, outcome and factors associated with mortality. Clin Infect Dis. 1999;29:1561-3.

28. Mazzonelli J, Mazzonelli GD, Mailloux M. Recherches sur les antigènes des leptospires. Tropenmed Parasitol. 1975;26:35-42.

29. McBride AJ, Athanazio DA, Reis MG, Ko AI. Leptospirosis. Curr Opin Infect Dis 2005; 18:376-86

30. Mederos R, Casas-Olascoaga R. Leptospirosis en el perro (Su comprobación en el Uruguay). An Fac Vet (Uruguay). 1959;9(7):171-92.

31. National Statistics Institute/INE. Uruguay in figures. [Cited 2011, February 15]. Available from: http://www.ine.gub.uy

32. Oliveira FCS, Azevedo SS, Pinheiro SR, Batista CSA, Moraes ZM, Souza GO, et al Fatores de risco para a leptospirose em fêmeas bovinas em idade reprodutiva no Estado da Bahia, Nordeste do Brasil. Pesq Vet Bras. 2010;30:398-402

33. Panaphut T, Domrongkitchaiporn S, Thinkamrop B. Prognostic factors of death in leptospirosis: a prospective cohort study in Khon Kaen, Thailand. Int J Infect Dis. 2002;6:52-9.

34. Pereira MM, Matsuo MG, Bauab AR, Vasconcelos SA, Moraes ZM, Baranton G, et al. A clonal subpopulation of Leptospira interrogans sensu stricto is the major cause of leptospirosis outbreaks in Brazil. J Clin Microbiol. 2000;38:450-2.

35. Pisano I, Marra A, Pomi A, Boero A. Leptospirosis con compromiso miocárdico. Cuad Med Interna. 1997; 1:51-5.
36. Rajapakse S, Rodrigo C, Haniffa R. Developing a clinically relevant classification to predict mortality in severe leptospirosis. J Emerg Trauma Shock. 2010;3:213-9.

37. Repiso MV, Gil A, Bañales PM, D’Anatro N, Fernández L, Guarino H, et al. Prevalencia de las principales enfermedades infecciosas que afectan el comportamiento reproductivo en la ganadería de carne y caracterización de los establecimientos de cría del Uruguay. Veterinaria (Montevideo). 2005;40(157):5-28.

38. Rosetti C, Cacchione R, Farace MI, Mazzonelli D, Brihuega B. Curso teórico-práctico de introducción al diagnóstico de la leptospirosis animal. Castelar: Instituto Nacional de Tecnologia Agropecuaria; 1999.

39. Schoonman L, Swai ES. Herd-and animal-level risk factors for bovine leptospirosis in Tanga region of Tanzania. Trop Anim Health Prod. 2010;42:1565-72.

40. Scialfa E, Bolpe J, Bardón JC, Ridao G, Gentile J, Gallicchio O. Isolation of Leptospira interrogans from suburban rats in Tandil, Buenos Aires, Argentina. Rev Argent Microbiol. 2010;42:126-8

41. Shang ES, Summers TA, Haake DA. Molecular cloning and sequence analysis of the gene encoding LipL41, a surface-exposed lipoprotein of pathogenic Leptospira species. Infect Immun. 1996;64:2322-30.

42. Shuang-Xi Ren, Gang Fu, Xiu-Gao Jiangk, Rong Zeng, You-Gang Miao, Hai Xu, et al. Unique physiological and pathogenic features of Leptospira interrogans revealed by whole-genome sequencing. Nature. 2003;422:888-93.

43. Silva EF, Cerqueira GM, Seyffert N, Seixas FK, Hartwig DD, Athanazio DA, et al Leptospira noguchii and human and animal leptospirosis, Southern Brazil. Emerg Infect Dis. 2009;15:621-3.

44. Silva MV, Camargo ED, Batista L, Vaz AJ, Brandão AP, Nakamura PM, et al. Behaviour of specific IgM, IgG and IgA class antibodies in human leptospirosis during the acute phase of the disease and during convalescence. J Trop Med Hyg. 1995;98:268-72.

45. Smythe LD, Smith IL, Smith GA, Dohnt MF, Symonds ML, Barnett LJ, et al. A quantitative PCR (Taq Man) assay for pathogenic Leptospira spp. BMC Infect Dis 2002;2:13.

46. Tealdo MS, Romero GN, Autrey CD, Samartino L. Serología positiva a Leptospira interrogans, serovar cynopteri en caninos de la Ciudad de Buenos Aires, Argentina. InVet. 2007;9: 59-65.

47. Torten M, Shenberg E, Van der Hoeden J. The use of immunofluorescence in the diagnosis of human leptospirosis by a genus-specific antigen. J Infect Dis. 1966;166:537-43.

48. Turk N, Milas Z, Mojcec V, Ruzic-Sabljic E, Staresina V, Stritof Z, et al. Molecular analysis of Leptospira spp. isolated from humans by restriction fragment length polymorphism, real-time PCR and pulsed-field gel electrophoresis. FEMS Microbiol Lett. 2009;300:174-9.

49. Ursu M, Lombardi R. Insuficiencia renal aguda en la leptospirosis: análisis de 20 casos Paciente Crít. 1993;6:129-35.

50. Vieira ML, Gama-Simões MJ, Collares-Pereira M. Human leptospirosis in Portugal. A retrospective study of eighteen years. Int J Infect Dis. 2006;10:378-86.

51. WHO-ILS (International Leptospirosis Society). Human leptospirosis: guidance for diagnosis, surveillance and control. Terpstra WJ, Editor. Malta: WHO; 2003.

Received: 29 May 2011

Accepted: 3 January 2012 


\section{Revista do Instituto de Medicina Tropical de São Paulo on line.}

Publications from 1987 to the present data are now available on:

http://www.scielo.br/rimtsp

PAST ISSUES 1959-1989 (PDF)

www.imt.usp.br/portal/

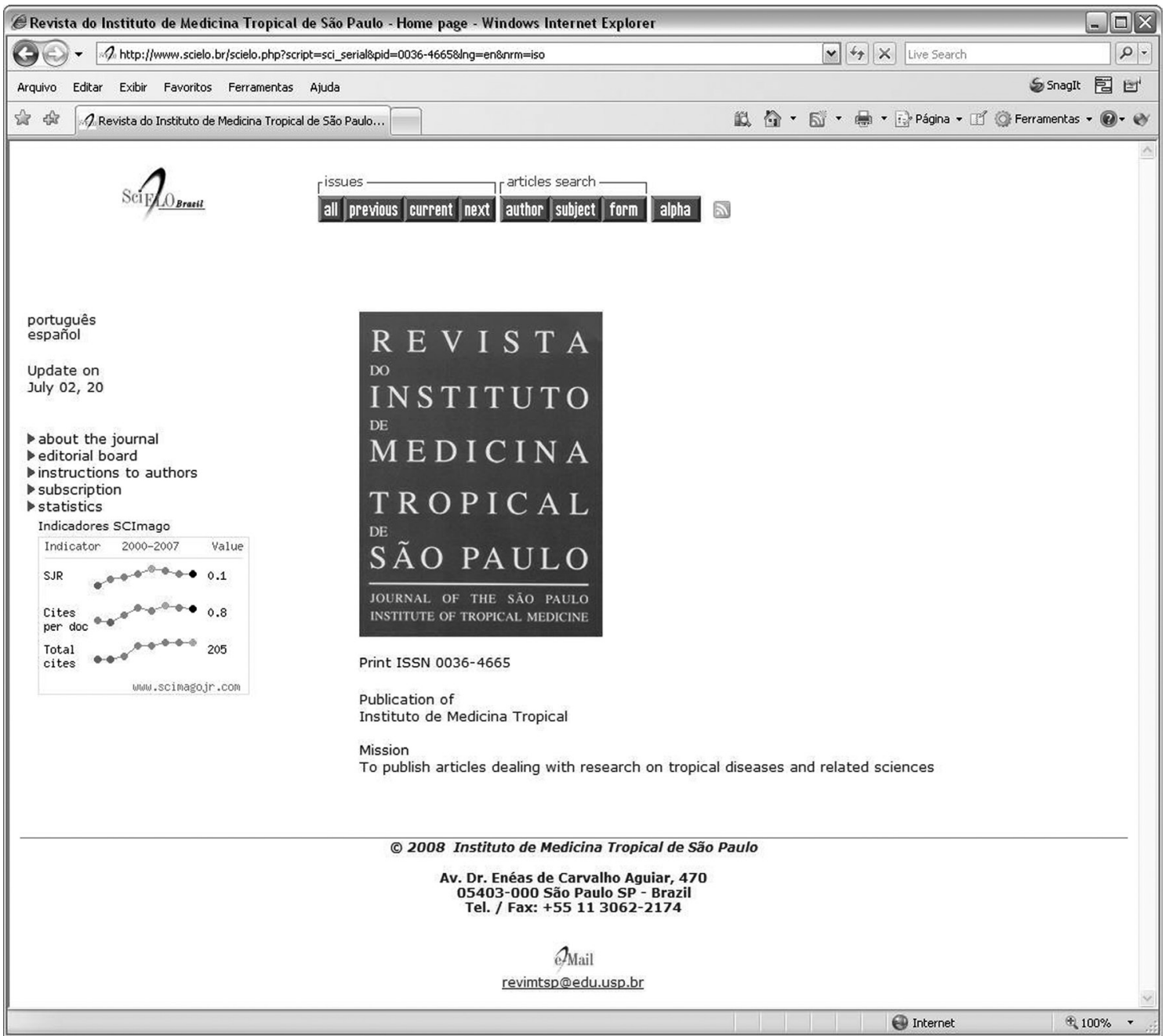

SciELO - The Scientific Electronic Library OnLine - SciELO is an electronic virtual covering a selected collection of Brazilian scientific journals.

The library is an integral part of a project being developed by FAPESP - Fundação de Amparo à Pesquisa do Estado de São Paulo, in partnership with BIREME - the Latin American and Caribbean Center on Health Sciences Information.

SciELO interface provides access to its serials collection via an alphabetic list of titles or a subject index or a search by word of serial titles, publisher names, city of publication and subject.

The interface also provides access to the full text of articles via author index or subject index or a search form on article elements such as author names, words from title, subject and words from full text.

FAPESP/BIREME Project on Scientific Electronic Publications Latin American and Caribbean Center on Health Sciences Information

Rua Botucatu 862 - 04023-901 São Paulo, SP - Brazil

Tel. (011) 5576-9863

scielo@bireme.br 